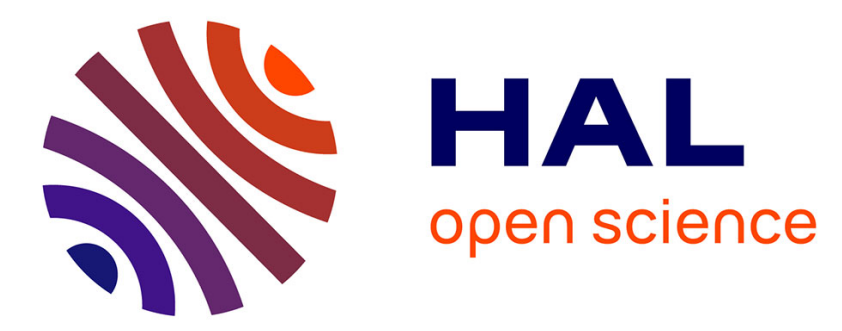

\title{
Theme E: disabilities: analysis models and tools
}

Nadine Vigouroux, Philippe Gorce, Agnès Roby-Brami, Olivier Rémi-Néris

\section{To cite this version:}

Nadine Vigouroux, Philippe Gorce, Agnès Roby-Brami, Olivier Rémi-Néris. Theme E: disabilities: analysis models and tools. Innovation and Research in BioMedical engineering, 2013, 34 (1), pp.14-15. 10.1016/j.irbm.2013.01.002 . hal-01154248

\section{HAL Id: hal-01154248 \\ https://hal.science/hal-01154248}

Submitted on 21 May 2015

HAL is a multi-disciplinary open access archive for the deposit and dissemination of scientific research documents, whether they are published or not. The documents may come from teaching and research institutions in France or abroad, or from public or private research centers.
L'archive ouverte pluridisciplinaire HAL, est destinée au dépôt et à la diffusion de documents scientifiques de niveau recherche, publiés ou non, émanant des établissements d'enseignement et de recherche français ou étrangers, des laboratoires publics ou privés. 


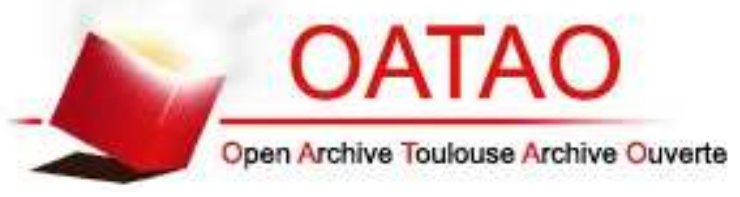

\section{Open Archive TOULOUSE Archive Ouverte (OATAO)}

OATAO is an open access repository that collects the work of Toulouse researchers and makes it freely available over the web where possible.

This is an author-deposited version published in : http://oatao.univ-toulouse.fr/ Eprints ID : 12831

To link to this article : DOI:10.1016/j.irbm.2013.01.002

URL : http://dx.doi.org/10.1016/j.irbm.2013.01.002

To cite this version : Vigouroux, Nadine and Gorce, Philippe and Roby-Brami, Agnès and Rémi-Néris, Olivier Theme $E$ : disabilities : analysis models and tools. (2013) IRBM, vol. 34 ( $\mathrm{n}^{\circ}$ 1). pp. 14-15. ISSN 1959-0318

Any correspondance concerning this service should be sent to the repository administrator: staff-oatao@listes-diff.inp-toulouse.fr 


\title{
Digital technologies for healthcare
}

\section{Theme E: Disabilities: Analysis models and tools}

\author{
N. Vigouroux ${ }^{\mathrm{a}, *}$, P. Gorce $^{\mathrm{b}}$, A. Roby-Brami ${ }^{\mathrm{c}}$, O. Rémi-Néris $^{\mathrm{d}}$ \\ a IRIT, UMR CNRS 5505, Université Paul-Sabatier, 31062 Toulouse cedex 09, France \\ ${ }^{\mathrm{b}}$ Laboratoire Handibio EA 4322, Université du Sud-Toulon, BP 20132, La Garde, France \\ c ISIR, UPMC/CNRS UMR 7222, Pyramide T55/65, 4, place Jussieu, 75005 Paris, France \\ ${ }^{\mathrm{d}}$ LaTIM. U 650, CHU Morvan, 5, avenue Foch, 29609 Brest cedex, France
}

\begin{abstract}
This paper presents the topics and the activity of the theme E "disabilities: analysis models and tools" within the GDR STIC Santé. This group has organized a conference and a workshop during the period 2011-2012. The conference has focused on technologies for cognitive, sensory and motor impairments, assessment and use study of assistive technologies, user centered method design and the place of ethics in these research topics. The objective of "bodily integration of technique" workshop, organized in the framework of Défi Sens (CNRS) was to develop a multidisciplinary approach (physiology, robotics and anthropology) of the relationships between body and technology taking as an example the prostheses for the compensation of sensorimotor disabilities. Efforts will focus on strengthening the development of a multidisciplinary research for the design of assistive technologies for elderly people and people with disabilities. The modelling of the user's abilities and the designing of adaptable AT to the needs of the person will be carried out with other groups of this GDR and also with other GDRs.
\end{abstract}

\section{Aims}

Designing an efficient and adaptable assistive technology (AT) is intrinsically difficult since this process:

- involves a variety of expertise (from information communication technologies to rehabilitation medicine for example including ergonomics);

- must compensate for different disabilities (motor, sensory and cognitive);

- must consider several levels of handicap depending on the interaction between personal factors that occurs or not as a consequence of a disability and environmental factors that determine the activity of the person and the tasks being performed

The WHO international classification of functioning, disability and health (ICF) is used to categorize the disabilities being assisted [1].

\footnotetext{
* Corresponding author.

E-mail address: vigourou@irit.fr (N. Vigouroux).
}

Research projects at the international level, such as the cardiac [2] and braid [3] are currently defining roadmaps on methods and tools for designing AT and services integrated these AT. Numerous emerging scientific questions at various steps of the AT design can be found in the literature. Some of them concern:

- the implication of age related changes in cognition AT [4,5];

- the variation in the ability of the disabled that involves defining adaptive process of the human computer interaction component of the AT $[5,6]$;

- the definition of a multidimensional assessment including usability, ethical and social criteria;

- the movement analysis as an input for the design of AT; for instance manipulability cues to quantify the functional patient's abilities [7];

- methods and models for taking into account all the components of social environment of disabled persons;

- research grounded on sensory motor theories of perception for perceptual applied for the accessibility of digital spaces [8];

- the emerging of new discipline such as the neurorehabilitation to better understand the process of motor learning in the context of recovery after a neural lesion. 
This discipline involves kinematic models, studies on the role of sensori-moteur interaction, technologies dedicated to rehabilitation, for example [9].

These challenges can be addressed through a close collaboration between different fields such as human computer interaction, cognition, movement analysis, and ergonomics, etc. with a very close interaction with end user association and clinicians.

So, the theme E aims to promote collaboration between these different disciplines, in order to propose methods, tools, models and evaluation platforms, applied to the design of useful and efficiency AT.

\section{Results for the period 2011-2012}

January 17-19, 2011: "the use of ICT for greater autonomy: interdisciplinary research". This conference of three whole-days was sponsored by the GDR STIC Santé. The objectives were to:

- to present the progress of current work on assistive technologies;

- to discuss on the place of re-education centre, clinical teams both on the design and evaluation process;

- to review current initiatives for ethic consideration.

Presentations have covered several fields: perception (analysis, characterization and modelling); movement studies (biomechanical modelling neuro-rehabilitation); modelling tools of the human process for disabled and elderly people; design and evaluation methods of AT, etc.

November 29-30, 2012: workshop "bodily integration of technic". Organized by N. Jarrasse and A. Roby-Brami (ISIR UPMC-CNRS UMR 7222) and M. Maestrutti (Cetcopra, Université Paris Panthéon Sorbonne) in the framework of Défi Sens CNRS (P.Sommer, CNRS Mission pour l'interdisciplinarité) with the support of ISCC-CNRS (V. Donzeau-Gouges, E. Kleinpeter, B. Brémont) and GDR Stic santé. The workshop was organized in ISIR and 60 persons participated.

The objective was to develop a multidisciplinary approach (physiology, robotics and anthropology) of the relationships between body and technology taking as an example the prosthesis for the compensation of sensorimotor disabilities. Sixteen participants presented a contribution. The presentations were organized into four sessions:

- tools and technique;

- motor control and prostheses;
- body and disability;

- action, perception and enaction.

\section{Future plans (work in progress)}

Two main meetings are presently in progress. The first one will concern the role of use studies in the iterative design process of the alternative augmentative communication aids (combining pictograms and text mode). The second one will focus on the analysis of 10 research years on brain computer interface (BCI). Feedback of tested BCI will be held on interaction with the theme $\mathrm{B}$ and with GDR ISIS for the validation and identification limitations of the current methods of signal processing.

The future works will also focus on strengthening the interactions with the other topics of this GDR (mainly the theme $\mathrm{G}$, possibly leading to the definition of a joint action on the multidimensional assessment based on usability criteria and biomechanics cues). We will also establish a connection with the actions of the "Defi-Sens" program of the CNRS (http://www.cnrs.fr/mi/spip.php?article58) and the ASSISTH network. Efforts will be pursued to reinforce the collaboration on assistive robotics with GDR Robotique.

\section{References}

[1] Barbotte E, Guillemin F, Chau N, The Lorhandicap Group 4. "Prevalence of impairments, disabilities, handicaps and quality of life in the general population: a review of recent literature". Bull World Health Organ 2001;79:1047-55

[2] Gill J, Abascal J, "Acccessible user interfaces: priorities for research, advancing research and development in the area of accessible and assistive ICT", cardiac project (http://www.cardiac-eu.org deliverables/Accessible\% 20User\%20Interfaces.pdf), July 2012.

[3] Project BRAID, Bridging research in ageing and ICT development, "interim roadmap for ict and ageing", http://www.braidproject.eu/, February 2011.

[4] Gillespiea A, Besta C, O’Neill B. "Cognitive function and assistive technology for cognition: a systematic review". J Int Neuropsychol Soc 2012;18(1):1-19.

[5] Czaja SJ, Lee CC. "The impact of aging on access to technology". Univ Access Inf Soc 2007;5:341-9.

[6] Lepicard G, Vigouroux N. "Comparison between single-touch and multitouch interaction for older people". In: International Conference on Computers Helping People with Special Needs. 2012, 658-665.

[7] Jacquier-Bret J, Rezzoug N, Gorce P, "Effect of spinal cord injury at C6-C7 on global upper limb coordination during grasping: manipulability approach", IRBM, 2013, (present issue).

[8] Tixier M, Lenay C, Gapenne O, Aubert D, "From perceptual supplementation to the accessibility of digital spaces: the case of free exploration of city maps for blind persons", IRBM, 2013, (present issue).

[9] Van Dokkum L, Mottet D, Bonnin HY, Metrot J, Roby-Brami A, Hauret I, et al. "People post-stroke perceive movement fluency in virtual reality". Exp Brain Res 2012;218:1-8. 